\title{
Improving English Reading Comprehension Ability through Survey, Questions, Read, Record, Recite, Review Strategy (SQ4R)
}

\author{
Nurul Lailatul Khusniyah ${ }^{1}$, Yumna Rasyid ${ }^{2} \&$ Ninuk Lustyantie $^{2}$ \\ ${ }^{1}$ Universitas Islam Negeri Mataram, Indonesia \\ ${ }^{2}$ Language Education, Postgraduate of Universitas Negeri Jakarta, Indonesia \\ Corresponding: Nurul Lailatul Khusniyah, Universitas Islam Negeri Mataram, Indonesia. E-mail: \\ nurullaila@uinmataram.ac.id
}

Received: October 9, 2017 Accepted: November 16, 2017 Online Published: November 19, 2017

doi: 10.5539/elt.v10n12p202

URL: http://doi.org/10.5539/elt.v10n12p202

\begin{abstract}
The aim of this study is to examine the effect of the survey, questions, read, record, recite, review (SQ4R) strategy of the reading comprehension ability students of 2 nd semester. The research study was used action research method. The sampling was taken by 34 students. The validity of data used credibility, transferability, dependability, and conformability. Reading comprehension ability achievement questions prepared by the researcher. It was used as the data collecting tool. These questions were implemented to both groups before the experiment. Independent sample t-test was used for data analysis. The result of the study that t-test result is $\mathrm{t}$-stat (11.3)> t-table (1.997). It means that there is a significant difference was found in English reading comprehension ability in favour of the students who studied reading comprehension before and after the use of the SQ4R strategy.
\end{abstract}

Keywords: action research, English reading comprehension, SQ4R

\section{Introduction}

Language communicates meaning and allows the sharing of information, ideas, and perspectives. When written messages are able to understand, reading can be a wonderfully inspiring, enjoyable, and transforming experience. Because texts can offer alternative perspectives on the world and students' imagination to create new ways of thinking. It is necessary to get back to the importance of reading for meaning. Reading is central to teaching and learning and it considers the circumstances in which the developing child is required to extract and apply meaning derived from the text. Reading comprehension skills become more important as children progress through the educational system. Models of reading comprehension can help us to understand the different skills and processes involved in interpreting the text. The simple view of reading (Gough \& Tunmer, 1986) offers a useful model for characterising successful reading. Gough and Tunmer (1986 in Clarke, et al., 2014) propose that two skills are needed in order to read for meaning: the ability to recognize or pronounce the words (decoding) and the ability to understand spoken the language (listening comprehension).

According to Peregoy and Boyle (2005), that reading is a set of skills that involves making sense and deriving meaning from the printed words. For second language learners, there are three different elements that impact reading: the child's background knowledge, the child's linguistic knowledge of the target language and the strategy or techniques the child uses to tackle the text. What is presented by Peregoy and Boyle is an ideal framework for reading teaching and learning. Like as in reading learning process at English Study Program UIN Mataram has a vision of producing educators who are proficient in English reading. Students are also able to use appropriate reading strategies to understand information implicitly in the text, interpret textual content, recognize discourse markers, to identify the structure of texts, to develop and analyze different types of texts.

In the preliminary study, the researcher found the main problem of reading comprehension learning that comes from students, lecture, and facility of learning. Some students are not able to use reading strategies to comprehend the meaning. Problems sourced from students related to the learning process in the classroom. These are; 1) students still have difficulty interpreting the meaning of texts or synthesizing words, phrases or sentences into the precise meanings desired by the author's context; 2) a less reading source; 3) there are still many students who failed in reading learning, and 4) learning that is still centered on the teacher. Cunningham \& 
Stanovich (Willis, 2008) to comprehend text, the reader must be able to decode words or recognize words and access text integration processes to construct meaning and retain the content of the words long enough for it to stimulate their stores of related information in their long-term memories. Beginning comprehension instruction builds on children's linguistic and conceptual knowledge (Snow, Burns, \& Griffin, 1998 in Willis 2008) and includes explicit instruction on strategies such as summarizing, predicting, and self-monitoring for understanding. Thus, it can be concluded that in understanding the first-order readings that the reader must do is to understand each word with the stored meaning and integrate it as a whole.

The specific problem of reading comprehension that had found in the last research at English program UIN Mataram include finding new vocabulary, clarification of key concepts, linking to prior knowledge and personal relevance, instruction in strategies, student-centered discussions about the content, previewing, predicting, summarizing, selecting main ideas, self-monitoring, and teacher feedback for understanding. In reading comprehension learning is not only to understand the context meaning but also broader learning. As said by Oakhill (2015) that reading comprehension is important, not just for understanding text, but for broader learning, success in education, and employment. It is even important for our social lives, because of email, text, and social networking sites. Reading comprehension is a complex task, which requires the orchestration of many different cognitive skills and abilities. So, reading comprehension is not only understands the content but more broadly for learning, the success of education and work processes, but also for the benefit of social life. According to Grabe and Stoller (2002), reading for understanding is the ability to understand information in text and interpret it appropriately. Its different argument from Thomas Barret in Brassell and Rasinski (2008) has suggested the following three types of action with his three-level taxonomy of reading comprehension;

1) Literal Comprehension: Literal comprehension, the lowest of the three levels, requires a reader to be able to retell or recall the facts or information presented in a text.

2) Inferential Comprehension: Inferential comprehension, the next level, refers to the ability of a reader to take in information that is inferred or implied within a text.

3) Critical Comprehension: Critical or evaluative comprehension, the third and highest level in the taxonomy, involves making critical judgments about the information presented in the text.

All three levels of comprehension are important and need to be assessed. Another suggests that assessment of reading ability does not end with a measurement of understanding. Assessment of reading ability has a different purpose. Measurement of reading comprehension should help teachers monitor students' understanding and provide useful information for designing reading comprehension programs (Klinger, 2007). So it can be concluded that the comprehension of reading content has a diversity of types or types. It aims to learners or students able to have the ability to understand the reading as needed. Problem development to understand the reading also related to the learning process undertaken.

Traditional multiple-choice reading assessments are often intended to assess low-level comprehension strategies rather than imaginative and interpretive stances. In a lecture delivered at Teacher's College, Hill (Israel et al., 200) described the tensions between low-level operations and the more constructivist responses, which the distracters on multiple-choice tests often stimulate. In some contemporary assessment programs, different from traditional multiple-choice appraisals include the type of open questions that require students to interpret the text and maintain their interpretation. Contemporary assessments, such as the National Assessment of Educational Progress (NAEP), have such types of traditional assessments of multiple choice and open-ended questions that require explanation.

A different opinion emerged from Snow (2002) that reading comprehension as the process of simultaneously extracting and constructing meaning through interaction and involvement with written language. We use the words extracting and constructing to emphasize both the importance and the insufficiency of the text as a determinant of reading comprehension. Comprehension entails three elements: the reader who is doing the comprehending, the text that is to be comprehended, the activity in which comprehension is a part. From the framework of the elements that build the process of reading comprehension. Maria and Nikki (2008) have developed a reading comprehension learning model. This model is a development of the Snow model described earlier. This model can be done to improve the quality of the reading comprehension ability. Therefore, the researcher replaces the previously used learning strategy of lectures with learning strategies to understand the contents of reading. Strategies are relating to the cognitive, metacognitive and affective components of the SQ4R strategy. This strategy provides an opportunity for students to study systematically, effectively and efficiently. According to Wong (2009) that SQ4R is a six-step system for reading and comprehending textbook chapters: survey, question, read, record, recite, and review. SQ4R is based on SQ3R; a fourth "R" has been added to the 
system to remind students to take notes. As with any approach, skipping anyone step weakens the system. To gain the most benefit from this system, use all six steps shown;

1) Survey the chapter to get an overview.

2) Write Questions for each heading and subheading.

3) Read the information, one paragraph at a time.

4) Select a form of note taking to Record information.

5) Recite the important information from the paragraph.

6) Review the information learned in the chapter

SQ4R has a good influence on English language learning. Like as research conducted Başar and Gürbüz (2017) with the title "Effect of the SQ4R Technique on the Reading Comprehension of Elementary School 4th Grade Elementary School Students." The aim of this study is to examine the effect of SQ4R (Survey, Question, Read, Reflect, Recite, Review) technique of the reading comprehension ability of elementary school 4th-grade students. According to the results of the study, a significant difference was found in the reading comprehension skills in favour of the students who studied reading comprehension with the SQ4R technique.

Research conducted by Rika Susanti with the title "Teaching Reading Comprehension Descriptive Text by Combining Polar Opposite Strategy and SQ4R (Survey, Question, Read, Record, Recite and Review) Strategy at Junior High). Reading is one of the skills students must possess in addition to listening, speaking and writing. Reading can increase students' knowledge of many things. However, most students experience obstacles in the process of reading learning, such as the lack of ability of students to express their opinions in the discussion session and their lack of understanding of the text reading. The difficulties experienced by these students, caused by several factors, such as teachers only use one strategy in the learning process and the absence of activities that can provoke students to express their opinions. Therefore, students must combine the two strategies in the learning process. Another research conducted by Runiatun, Siti Istiyati, Matsuri, M. Ismail Sriyanto through the title "The Use of SQ4R Strategy (Survey, question, Read, Reflect, Recite, Review) to improve understanding reading skills." The purpose of this research is to improve the comprehension reading skill through SQ4R strategy in grade V students SDN Soropadan Np.108 Surakarta 2015/2016

Based on the above description, it can be concluded that the SQ4R strategy is the right choice for learning problem to understand the content of the reading which is supposed to improve reading comprehension of the students. Process students' improving reading comprehension of English Language Study Program at UIN Mataram can be done through action research. Grundy and Kemmis state (Skerritt, 2005) that:

Action research is research into practice, by practitioners, for practitioners... In action research, all actors involved in the research process are equal participants, and must be involved in every stage of the research... The kind of involvement required is collaborative involvement. It requires a special kind of communication... which has been described as 'symmetrical communication', which allows all participants to be partners of communication on equal terms... Collaborative participation in theoretical, practical and political discourse is thus a hallmark of action research and the action researcher.

Action in this research has some step. Action research creates new knowledge based on enquiries conducted within specific and often practical. It is action leading to personal or professional development. It is participatory in nature which led Elliot. Elliot's model incorporates the fact-finding-and-discovery-assessment process that exists at each step or stage of action research. This model has 3 stages. The first stage consists of identifying key ideas, gathering facts, inventions and analyzes, followed by a general plan into actions, evaluating influences, proceeding with revisions for the second phase. The second stage contains the actions that are followed by the evaluation step and its influence which then in the stage of improvement for the third stage. The third stage is also the same as the second stage to find good results and success.

The goal of this research is to examine the effect of SQ4R strategy on reading comprehension skills of second-semester students. These are the detail of problem:

1) How is the process of reading comprehension learning using the application of SQ4R?

2) How is the difference the reading comprehension skills before and after the application of SQ4R?

\section{Method of Research}

The research study was used action research method. Measures of action success applied in this research are seen both from the learning process and learning the result. Action will be declared successful if the student activity in 
following the learning process with an SQ4R strategy is to achieve good category marked at least reaches an average score of 75. Students have received the material in process of learning during 4 weeks. Before the learning process, they will do a pre-test and after 4 weeks, they have to do the post-test. In this action, pre-test and post-test results are too used in order to decide on the effectiveness of the independent variable.

The participant of research consists of a total 34 students from UIN Mataram in 2016-2017 academic years. The process of collecting data for this action research consists of several types;

a) Observation. It is as documentation and reflection learning process. Here is the instrument for observation:

Table 1. Guiding observation to assess teacher's activity

\begin{tabular}{lll}
\hline Indicator & Questions & Account question \\
\hline Learning activity & $\begin{array}{l}\text { Does teacher explain learning? } \\
\text { Does teacher give an instruction of learning } \\
\text { clearly? }\end{array}$ \\
$\begin{array}{l}\text { Students' participant in learning } \\
\text { process }\end{array}$ & $\begin{array}{l}\text { Does teacher facility of learning needs for } 3 \\
\text { students? } \\
\text { Evaluating of learning progress } \\
\text { Feedback process }\end{array}$ & $\begin{array}{l}\text { Does teacher evaluate the learning process? } \\
\text { Does teacher give feedback process for } 3 \\
\text { students' task? }\end{array}$ \\
\hline
\end{tabular}

b) Test. The question is reading multiple choose. Here is the component of reading comprehension test;

Table 2. Indicator of reading comprehension test

\begin{tabular}{|c|c|c|}
\hline Component & Indicator & Account point \\
\hline Literal comprehension & $\begin{array}{ll}\text { - } & \text { Identify word meaning } \\
\text { - } & \text { Meaning context }\end{array}$ & 13 \\
\hline Inferential comprehension & $\begin{array}{ll}\text { - } & \text { Identify the main idea } \\
\text { - } & \text { Identify relation in the text }\end{array}$ & 10 \\
\hline Critical comprehension & - $\quad$ Analyzing process of text & 7 \\
\hline
\end{tabular}

To determine the reliability of data, Lincoln and Guba use unique terms such as credibility, transferability, dependability, and conformability. Qualitative data were taken during the observation and action process, interview, and questionnaire. While the quantitative data were taken from pretest and post-test (preliminary and final test). The descriptive analysis technique was implemented in order to determine the students' activity learning progress for the first problem. The independent t-test technique was implemented to know the difference of students' ability before and after application of an SQ4R strategy for the second problem.

\section{Result}

\subsection{Process of Improving Reading Comprehension Learning After the Application of SQ4R}

Learning activity progress in the class has done using SQ4R strategy. Each step of learning process covered using the SQ4R strategy. Here are the step of learning in the class:

a. The first step; Survey. In this step, the teacher managed the learning at the introduction stage that is exploring the theme or topic of learning. This survey activity is aimed at a preliminary understanding of the topic of learning. Teachers have provided 20 minutes of learning time to explore and improve the understanding of learning topics. In this step also teachers direct students to understand about; reading titles, reading contexts, and students can understand the topic of the initial paragraphs of the text.

b. Step Two; Write Questions. In this step, the student has been directed at the understanding of the text through the exercises that have been provided. Activities undertaken by students in this step are between 10 to 15 minutes. 
c. Third step; Read Carefully. In this step, the students presented simple text reading then the teacher gave the time for 10 minutes to read. Teachers also always provide opportunities for students to read the text in front of the class.

d. Step Four; Record Information. The fourth step aims to define students' understanding of literal or contextual reading through recording activities or making notes and storing the information as material for doing the task. Teachers also provide time between 15-20 minutes to discuss together.

e. Step Five; Recite. In the fifth step, the researcher re-emphasizes the fourth step through rewriting what has been read and reread the text for doing the exercises. The insertion of writing back what has been read is helpful and it is assisting students in completing all questions. Teachers provide long enough time between 20-25 minutes to perform learning activities in this step. Thus, the result of the insertion of other activities in the fifth step reinforces the students' understanding of the learning done and is able to increase student activity in the previous step. Because the fourth step already has the activity of making small notes to the text being read.

f. Sixth Soul; Review. In this step, the teacher gives the opportunity to the students to review what has been learned in the previous step. The forms presented in the material vary from enriching vocabulary, writing summaries, identifying difficult vocabulary, finding meaning in words, or presenting students' understanding of English text.

Teacher's activity in the class has observed to know the effect of SQ4R strategy. It is a part of the learning process in the application of SQ4R. The teacher has main roles on English reading comprehension learning process. They have to manage the class as well as particularly in using time because the English reading comprehension learning is done by 90 minutes. Here the result of observation on teacher's activity during learning process:

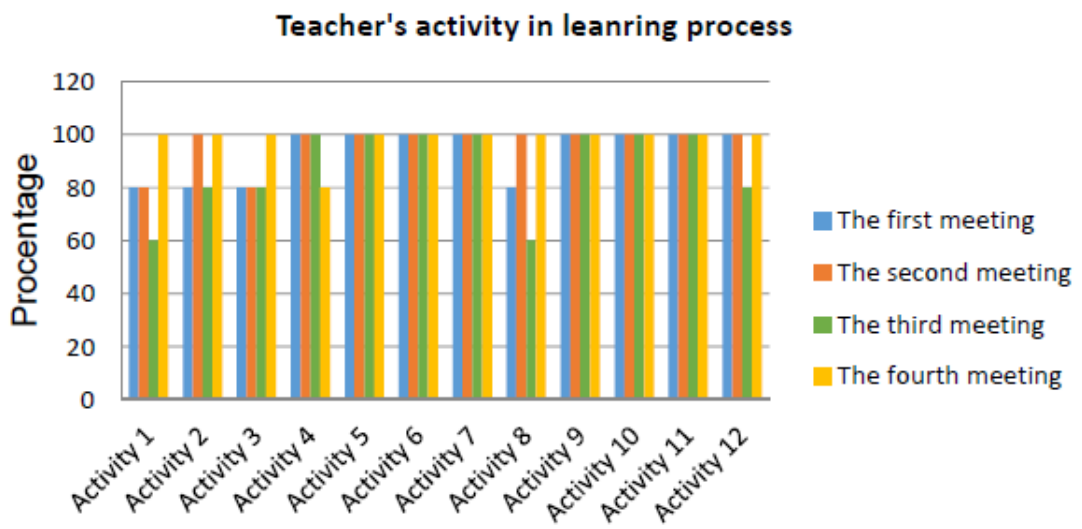

Figure 1. Teacher's activity in learning process

In the graph above shows the development of teacher's activity during the learning process. Of the 12 activities have been rated very well. From the results of the assessment showed that as many as $91.7 \%$ of the teacher's activities have been assessed by 100 . There is one teacher's activity is assessed only with a percentage of $80 \%$. Thus it is concluded that the teacher has been very optimal in improving English reading comprehension learning using SQ4R strategy. Moreover, the analysis data is taken from interview and discussion with students to know their response on SQ4R strategy. Some students give a positive response to teacher's activity. It can be seen from below chart; 


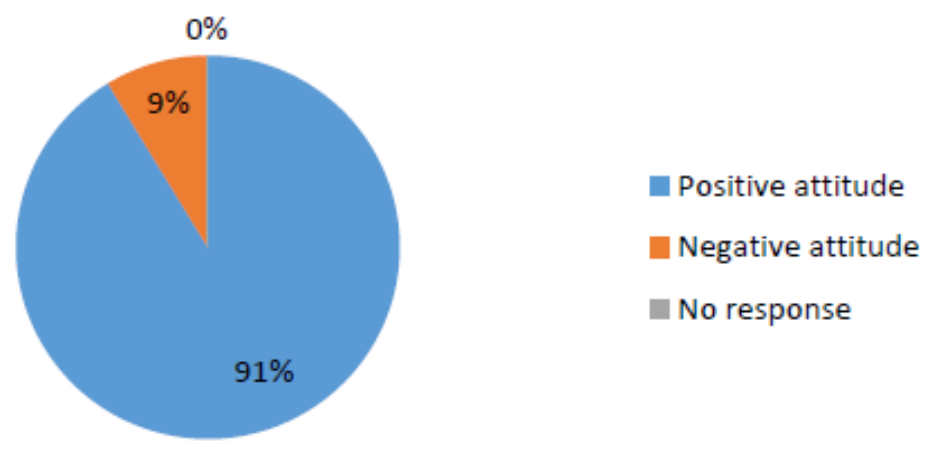

Figure 2. Students' response to teacher's activity in the application of SQ4R

The results of analysis observation data shown that the SQ4R strategy achievement of English reading comprehension has advantages and disadvantages. The disadvantages have found:

1) 90 minutes is not enough to learn English reading comprehension through SQ4R strategy. So that the deepening of the material must be done at home.

2) The teachers have to manage the time as well as from the start of preliminary learning until the closing because the SQ4R strategy has six steps.

3) The teachers have to prepare their own teaching materials in order that it is available with the needs of the SQ4R strategy so it takes a lot of time in preparing for learning

While the advantages of applying SQ4R strategy as follows:

1) The SQ4R strategy learning process has clearly and orderly stages.

2) Students can easily perform reading activities because each step presented varies.

3) Classroom learning is more easily controlled by teachers

4) The teacher can also establish stable interactions with students

5) Students can easily focus on the learning that wants to achieve

6) Students easily also manage their ability to understand the reading text

7) Learning activities are done repeatedly. Repetition learning is the key to successful learning

8) Students work on reading and reviewing the material on each heading before moving on the next page.

9) Developing the comprehension in the monitoring system or the guidance of learning.

Thus it is concluded that the use of SQ4R strategy in English reading comprehension learning at UIN Mataram has succeeded to improve students' reading comprehension ability which has been experiencing difficulties or difficulties. In addition, the SQ4R strategy also provides a complete understanding of the information through determining the required reading, repeating the learning repeatedly, and storing the information obtained for use at the next learning meeting. In addition, this strategy also enhances the liveliness of student critical patterns because it forces students to link what knowledge or information they have had with reading and developing it. Thus the analytical process also builds very well.

\subsection{The Difference of Reading Comprehension Skills before and After the Application of SQ4R}

The result of t-test conducted in order to determine the presence of a difference between the pre-test and post-test score of experimental and control group are presented in the following table:

Table 3. The difference between the pre-test and post-test score of experimental and control group

\begin{tabular}{lll}
\hline $\mathrm{t}$-Test result & & \\
& Pretest & Posttest \\
Mean & 68.18182 & 86.15152 \\
Variance & 38.40341 & 44.75758
\end{tabular}




\begin{tabular}{lll}
\hline Observations & 33 \\
Pooled Variance & 41.58049 \\
Hypothesized Mean Difference & 0 \\
$\mathrm{df}$ & 64 \\
$\mathrm{t}$ Stat & 11.31978 \\
$\mathrm{P}(\mathrm{T}<=\mathrm{t})$ one-tail & $3.18 \mathrm{E}-17$ \\
$\mathrm{t}$ Critical one-tail & 1.669013 \\
$\mathrm{P}(\mathrm{T}<=\mathrm{t})$ two-tail & $6.37 \mathrm{E}-17$ \\
$\mathrm{t}$ Critical two-tail & 1.99773 \\
\hline
\end{tabular}

The table above can be seen that t-stat (11.3)> t-table (1.997), which means Ho is rejected and H1 accepted, so it is known that English reading comprehension without SQ4R strategy $\neq$ English reading comprehension through SQ4R strategy. In other words, the use of SQ4R strategy can improve English reading comprehension skills significantly. It is seen that pre-test scores of students from experimental and control group have differences point. Pre-test average of students from experimental group was found 68.2 and that of the students from the control group was found 86.15. It shows that the SQ4R strategy has effect for each other. Before the reading comprehension learning used SQ4R strategy, students' ability is lower. Like as research carried out by Başar and Gürbüz (2017) with the title "Effect of the SQ4R Technique on the Reading Comprehension of Elementary School 4th Grade Elementary School Students." The aim of this study is to examine the effect of SQ4R (Survey, Question, Read, Reflect, Recite, Review) technique of the reading comprehension ability of elementary school 4th-grade students. According to the results of the study, a significant difference was found in the reading comprehension skills in favour of the students who studied reading comprehension with the SQ4R technique. So that, the SQ4R strategy is not only available for elementary students but also college students. It can be known that various strategy and activities implemented during learning process make a contribution to the reading comprehension skills. 34 students were subjected to a performance test to measure the level comprehension. Here is the t-test result for each level comprehension:

Table 4. T-test result of literal comprehension level

\begin{tabular}{lll}
\hline & Pretest & posttest \\
\hline Mean & 51.79411765 & 56.32353 \\
Variance & 134.0472371 & 113.9831 \\
Observations & 34 & 34 \\
Pooled Variance & 124.0151515 & \\
Hypothesized Mean Difference & 0 & \\
Df & 66 & \\
t Stat & 2.676983889 & \\
P(T $<=t)$ one-tail & 0.049138107 & \\
t Critical one-tail & 1.668270514 & \\
$\mathrm{P}(\mathrm{T}<=\mathrm{t})$ two-tail & 0.098276214 & \\
$\mathrm{t}$ Critical two-tail & 1.996564419 & \\
\hline
\end{tabular}

The table above can be seen that $\mathrm{t}$-stat (1.676) $>\mathrm{t}$-table (1.997), which means Ho is rejected and H1 accepted, so it is known that the use of SQ4R strategy can improve English reading comprehension skills significantly in literal comprehension level. 
Table 5. T-test result of interpretation comprehension level

\begin{tabular}{lll}
\hline & Pretest & Posttest \\
\hline Mean & 48.61765 & 55.79412 \\
Variance & 118.4251 & 72.47148 \\
Observations & 34 & 34 \\
Pooled Variance & 95.44831 & \\
Hypothesized Mean Difference & 0 & \\
df & 66 & \\
$\mathrm{t}$ Stat & 3.028665 & \\
$\mathrm{P}(\mathrm{T}<=\mathrm{t})$ one-tail & 0.001752 & \\
$\mathrm{t}$ Critical one-tail & 1.668271 & \\
$\mathrm{P}(\mathrm{T}<=\mathrm{t})$ two-tail & 0.003503 & \\
$\mathrm{t}$ Critical two-tail & 1.996564 & \\
\hline
\end{tabular}

The table above can be seen that $\mathrm{t}$-stat (3.028) > t-table (1.997), which means Ho is rejected and H1 accepted, so it is known that the use of SQ4R strategy can improve English reading comprehension skills significantly in interpretation comprehension level.

Table 6. T-test result of critical comprehension level

\begin{tabular}{lll}
\hline & Pretest & Posttest \\
\hline Mean & 51.58824 & 57.97059 \\
Variance & 97.34046 & 70.21123 \\
Observations & 34 & 34 \\
Pooled Variance & 83.77585 & \\
Hypothesized Mean Difference & 0 & \\
df & 66 & \\
t Stat & 2.975053 & \\
$\mathrm{P}(\mathrm{T}<=\mathrm{t})$ one-tail & 0.002716 & \\
t Critical one-tail & 1.668271 & \\
$\mathrm{P}(\mathrm{T}<=\mathrm{t})$ two-tail & 0.005432 & \\
$\mathrm{t}$ Critical two-tail & 1.996564 & \\
\hline
\end{tabular}

The table above can be seen that $\mathrm{t}$-stat (2.975)> t-table (1.997), which means Ho is rejected and H1 accepted, so it is known that the use of SQ4R strategy can improve English reading comprehension skills significantly in critical comprehension level.

Based on the above data, it is shown that English reading comprehension learning can be improved using SQ4R strategy. It refers for each level comprehension which is literal, interpretation and critical level. Students' level comprehension ability is better than before the use of SQ4R strategy. It is seen in the following chart: 


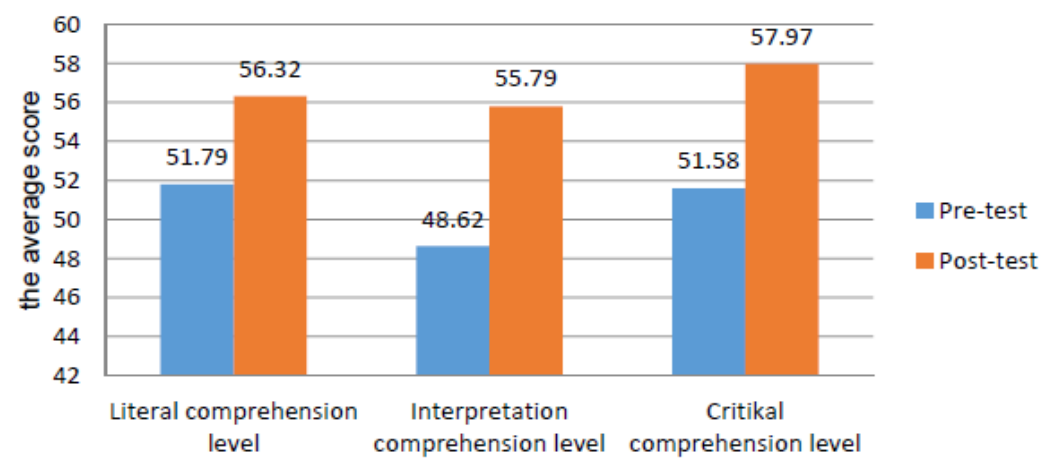

Figure 3. The average score of reading comprehension level

This research has implications for several components:

The first implication is the application of SQ4R strategy. The SQ4R strategy can be explored or combined with other activities such as rewrite. So, this strategy is a better influence on student progress learning. This strategy can also be used in advanced reading courses or other subjects. This is because the basic theory in this strategy is easy and flexible to suit the learning needs. Thus, the strategy can be one of the recommended learning strategies, especially reading learning

The second implication is management classroom. The SQ4R strategy can be applied to large classes with a total of over 30 students. However, faculty needs to work harder to design classroom learning. As in English reading learning at UIN Mataram that has 34 students for one class who have been experiencing difficulties especially in English reading comprehension have increased. These are three level of comprehension skills that is literal understanding, interpretation understanding and critical understanding.

As for the English lecturer, the successful implementation of the SQ4R strategy becomes an option in the teaching and learning process of reading that can also be used in other course learning. So that the results of this study can be used as a guide to design syllabus or learning plan reading courses. In addition, the results of this study can also be used as a guide to prepare teaching materials that are adjusted to the needs and stages in the SQ4R strategy. For students, the SQ4R strategy learning can feel more fun. From the results of the research indicate that this strategy also can build student's thinking pattern more critical and creative. They have a positive attitude in building cooperation among friends or learning environment. In addition, they also become more independent in learning.

The third implication is managerially related to stakeholders that are the policy stakeholder in English Department at UIN Mataram. The English education consortium can utilize the results of this research for the development of teaching and learning process in various subjects.

\section{Conclusion}

Based on the results of findings and analysis data can be concluded that the learning process using SQ4R strategy has learning stages that traceable and easy to understand by students. So that, the SQ4R strategy makes it easy for students to comprehend English reading text. Teacher's activity has also influenced the use of this strategy. Moreover, during the process of applying the strategy, the teacher has maximized this strategy more optimally. This is influenced also by the presentation of teaching materials that have been lecturers adjusted to the steps in the strategy SQ4R. Therefore, students' reading comprehension ability can be improved. It is seen from the result of the test. There is the difference between before and after using SQ4R strategy. The control group has average score 68.2 and the experimental group has average score 86.15. T-test result shows that t-stat (11.3) $>$ t-table (1.997). While t-test result of each comprehension level is the difference. Literal comprehension level has t-stat (1.676)> t-table (1.997), interpretation comprehension level has t-stat (3.028) $>\mathrm{t}$-table (1.997), and critical comprehension level has t-stat (2.975)> t-table (1.997), so it is seen a significant difference in favor of the experimental and control group for each comprehension level test. In other words that SQ4R strategy can improve English reading comprehension skills significantly.

\section{Suggestion}

The suggestions for the result of research are; 
a. English program study at UIN Mataram. Teachers may use SQ4R strategy in Bahasa and another subject. However, the teacher could be studied more deeply of the problem in the order they can create available material.

b. Students' reading comprehension skill improves affect to use the English book source for learning.

c. SQ4R strategy can be added to the teacher's guidebook in their textbook that has made.

\section{References}

Brassell, D., \& Timothy, R. (2008). Comprehension That Works Taking Students Beyond Ordinary Understanding to Deep Comprehension. CA: Shell Education.

Blachowicz, C., \& Donna, O.. (2008). Reading Comprehension Strategies for Independent Learners second edition. New York: The Guilford Press

Başar, Murat dan Mehmet Gürbüz. (2017). Effect of the SQ4R Technique on the Reading Comprehension of Elementary School 4th Grade Elementary School Students. International Journal of Instruction, 10(2). https://doi.org/10.12973/iji.2017.1029a

Chair, C. S. (2002). Reading for Understanding Toward an R\&D Program in Reading Comprehension. CA: Rand.

Clarke. (2014). Developing Reading Comprehension. UK: John Wiley \& Sons, Ltd, 2014.

Grabe, W., \& Fredricka, L. S. (2002). Teaching and Researching Reading. London \& New York: Routledge.

Israel, S. E. (2005). Metacognition in Literacy Learning Theory, Assessment, Instruction and Professional Development. Mahwah: Lawrence Erlbaum Associates, Inc,

Koshy, V. (2005). Action Research for Improving Practice A Practical Guide. London: Paul Chapman Publishing,

Klingner, J. K. (2007). Teaching Reading Comprehension to Students with Learning Difficulties. New York: The Guilford Press

Linse, C. T. (2005). Practical English Language Teaching: Young Learners. New York: McGraw-Hill.

Oakhill, J., Kate, C., \& Carsten, E. (2015). Understanding and Teaching Reading Comprehension A Handbook. London \& New York: Routledge.

Runiatun, Siti Istiyati, Matsuri, M.Ismail Sriyanto. Penggunaan Strategi SQ4R (Survei, question, Read, Reflect, Recite, Review) untuk Meningkatkan Keterampilan membaca Pemahaman. http://jurnal.fkip.uns.ac.id/index.php/pgsdsolo/article/viewFile/8865/6687

Skerritt, O. Z. (2005). New Directions in Action Research. London: The Falmer Press.

Susanti, R. Teaching Reading Comprehension Descriptive Text by Combining Polar Opposite Strategy and SQ4R (Survey, Question, Read, Record, Recite and Review) Strategy at Junior High), http://download.portalgaruda.org/article

Wong, L. (2009). Essential Study Skills Sixth Edition. New York: Houghton Mifflin Company.

Willis, J. (2008). Teaching the brain to read strategies for improving fluency, vocabulary and comprehension. Alexandria: ASCD.

\section{Copyrights}

Copyright for this article is retained by the author(s), with first publication rights granted to the journal.

This is an open-access article distributed under the terms and conditions of the Creative Commons Attribution license (http://creativecommons.org/licenses/by/4.0/). 